\title{
Relationship Between the Selected Factors with Entrepreneurial Career Aspirations Among Students of Community Colleges in Malaysia
}

\section{Tie Seng Te, Arnida Abdullah, and Abdullah Rashid Mat}

Faculty of Educational Studies, Universiti Putra Malaysia, Malaysia

\section{Abstract}

The purpose of this study is to identify the relationship between the selected factors and the entrepreneurial career aspirations among the community college students in Malaysia. The selected factors are attitude toward entrepreneurship, subjective norms, entrepreneurial self-efficacy, and entrepreneurial exposure. A total of 280 students from 8 community colleges in the selected states were chosen to participate in this study. Cluster random sampling was applied in selecting the samples. After the data

Corresponding Author:

Tie Seng Te

tie_te@yahoo.com

Received: 11 January 2019

Accepted: 14 February 2019

Published: 25 March 2019

Publishing services provided by Knowledge E

(c) Tie Seng Te et al. This article is distributed under the terms of the Creative Commons

Attribution License, which permits unrestricted use and redistribution provided that the original author and source are credited.

Selection and Peer-review under the responsibility of the 3rd ICTVET 2018 Conference Committee. cleaning process, 265 usable responses were used for analysis. Pearson correlation analysis was used to identify the relationship between the selected factors with entrepreneurial career aspirations. The findings in this study indicated that there is a significant positive relationship between attitude toward entrepreneurship ( $r=0.597, p$ $<0.01$ ), subjective norm ( $r=0.327, p<0.01)$, entrepreneurial self-efficacy ( $r=0.362$, $p<0.01)$, and entrepreneurial exposure $(r=0.263, p<0.01)$ with entrepreneurial career aspirations. Based on the findings of this study, it can be concluded that the attitude toward entrepreneurship is the main factor motivating students to pursue entrepreneurial career. Through the findings, the practitioners are recommended to advocate the benefits and outcomes of entrepreneurship in order to encourage students to pursue entrepreneurial career.

Keywords: entrepreneurial career aspirations, attitude toward entrepreneurship, subjective norm, entrepreneurial self-efficacy, entrepreneurial exposure, technical and vocational education and training (TVET)

\section{Introduction}

\subsection{Background}

At present, there are many TVET institutions in Malaysia offering a wide range of technical and vocational skills training to the students. The TVET institutions include vocational colleges, community colleges, polytechnics, the Industrial Training Institutes (ILP), 
the National Youth Skills Institutes, GIATMARA and the National Agricultural Training Council (NATC). Among all the institutions which offer technical and vocational training, the community colleges have proven its role as one of the most successful institutions in meeting the needs of the country. Based on the Graduates Tracer Study Report by the Ministry of Education (MoE), graduates from community colleges recorded the highest percentage of employability as compared to other higher education institutions [1]. In addition, community college graduates also recorded the highest percentage of self-employed rate [1]. About $10 \%$ of its graduates chose to be self-employed after graduation in the recent years. Those achievements enable the community colleges to gain increasing popularity among the local community in Malaysia as the number of community colleges continue to grow to meet the demand of the community.

Proving its success in producing a significant number of graduates who are selfemployed, makes for worthy research into the entrepreneurial attributes among the students of community colleges. This study is believed to be able to give insights for the respective parties to cultivate the goal to pursue entrepreneurial career among students as past studies have indicated that determination or intention is the best predictor to actual entrepreneurial behavior [2, 3]. Subsequently, it helps to encourage the development of entrepreneurship which has proven its roles in mitigating unemployment and economic growth $[4,5]$.

\subsection{Problem statement}

Acknowledging the roles of entrepreneurship, the Malaysian government has drawn various initiatives and measures into encouraging entrepreneurial activities among Malaysians. However, entrepreneurship is not seen as a main career option by most Malaysians, despite the efforts initiated by the government. Based on Global Entrepreneurship Monitor (2017), entrepreneurship is seen as a good career option by only 44.1\% Malaysians. The GEM (2017) report also revealed that Malaysia's Total Earlystage Entrepreneurial Activity (TEA) rate was the lowest in the Asia and Oceana regions. In terms of entrepreneurial intention, Malaysia was ranked 63 out of 64 countries listed in GEM, with the entrepreneurial intention rate of only $4.9 \%$ [6]. The Job Status Update by MoE (2010-2015) also indicated that more than $90 \%$ of the graduates worked as employees. Many Malaysian graduates do not regard entrepreneurship as a popular career option, as they prefer to opt for public or private jobs $[7,8]$. The low perforation into entrepreneurship among the students is an area which is worth exploring, to allow 
more effective ways of implementation for enhancement of entrepreneurial interest among Malaysians.

Besides that, personal attributes as posited in the Theory of Planned Behaviour [9] are commonly used by most of the researchers in studying entrepreneurial intentionality concept. However, not much is known about entrepreneurial exposure, which is an external influence factor. The Social Cognitive Career Theory [10] stated that external interaction with other people does impact one's career decision. Similarly, [11] also suggested the entrepreneurship involves the interaction between individuals and the environment in identifying entrepreneurial opportunities. Thus, besides personal attributes, the social influence factor does need to be studied as well.

\subsection{Research objectives}

1. to determine the relationship between attitude toward entrepreneurship and entrepreneurial career aspirations;

2. to determine the relationship between subjective norms and entrepreneurial career aspirations;

3. to determine the relationship between entrepreneurial self-efficacy and entrepreneurial career aspirations;

4. to determine the relationship between entrepreneurial exposure and entrepreneurial career aspirations.

\subsection{Research conceptual framework}

Based on the reference to the Theory of Planned Behaviour [9], the Social Cognitive Career Theory [10] and past studies, the researcher has identified four factors in researching entrepreneurial career aspirations among the students of community colleges. The first factor is attitude toward entrepreneurship, which is defined as the students' belief toward the benefits and possible outcomes derived from entrepreneurial career. The second factor is subjective norm, refers to the perceived support from significant others and the surrounding culture. The third factor is entrepreneurial selfefficacy, which is about students' belief in their ability to perform entrepreneurial tasks. The fourth factor is about the entrepreneurial experience or exposure gained by the students. 


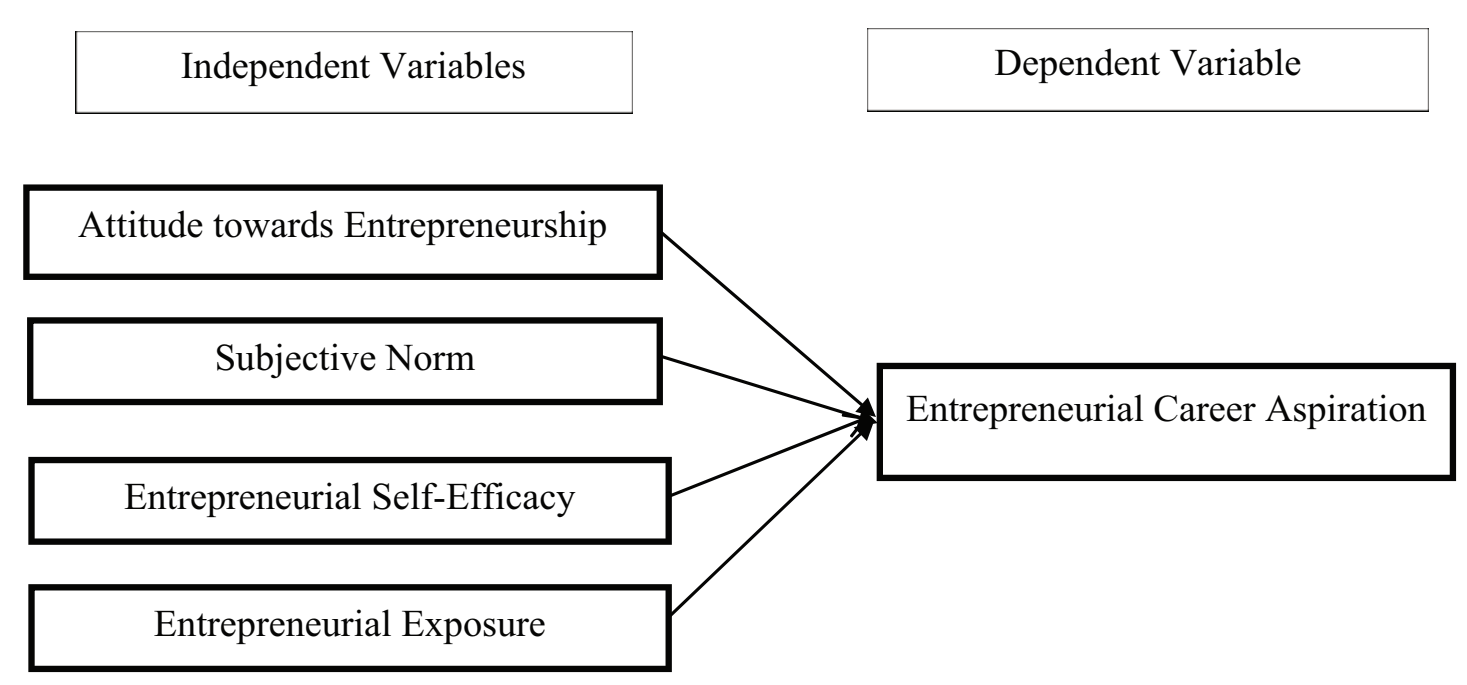

Figure 1: Research conceptual framework.

\section{Methodology}

This study applies correlational research design. The researchers use this research design to examine the entrepreneurial attributes which are likely to influence the students' entrepreneurial career aspirations. The population for this study is the final year community college students from Kedah, Pahang and Perak. These three states were chosen because graduates from these states recorded the highest percentage of self- employed rate in the recent years [12].

Cluster random sampling was utilized in selecting the samples. This sampling method was used as it is suitable for large number of clusters [13]. In this study, there is a total of 33 clusters as the researcher selected the samples according to the community college cluster. Besides that, the respondents in this study are geographically scattered. According to [14], cluster random sampling is appropriate to be adapted if the selection of individual population samples is difficult. From the total number of 33 clusters, 8 clusters of community colleges were selected to take part in this study based on the fishball technique. The selection based on the fishball technique enables every cluster to have the equal chance to be selected in the study.

Based on the data by Department of Community College Education Malaysia, there are 715 final semester students from the three states who will be going on industrial training. To determine the sample size, the researcher adapted Cochran's sample size calculation with confidence level of 95\% [15]. Based on the calculation, 250 samples were needed for this study. The researcher distributed 280 sets of questionnaires to the students. The distribution of extra number of questionnaires was acceptable in accordance with the proposition by [16] which suggested that a larger sample is 
more desirable to increase the representativeness of the population. From the total distribution of 280 questionnaires, 276 completed questionnaires were returned, which contributed to a return rate of $98 \%$. After data cleaning process, 265 responses were usable for analysis.

The researcher used questionnaires as the main instrument to collect data from the respondents. The questionnaire items are presented in the Appendix. The items were measured based on a 5-point Likert scale. The constructs in the instrument have high reliability, ranged from $\alpha=0.751$ to $\alpha=0.910$.

The data was then coded and analyzed using SPSS 23.0. The Pearson correlation analysis was used to determine the relationship between the selected factors and entrepreneurial career aspirations. The correlation value $(r)$ was interpreted based on the Pearson correlational analysis interpretation by [17]. Table 1 illustrates the Pearson correlation interpretation scale.

TABLE 1: Pearson correlation interpretation scale.

\begin{tabular}{l|c|}
$\begin{array}{l}\text { Size } \\
r=0.10 \text { to } 0.29 \text { or } r=-0.10 \text { to }-0.29\end{array}$ & Interpretation \\
$r=0.30$ to 0.49 or $r=-0.30$ to -0.49 & Moderate \\
$r=0.50$ to 1.0 or $r=-0.50$ to -1.0 & Strong \\
Source: Cohen, 1988. &
\end{tabular}

\section{Results}

The respondents in this study are final year community college students. From the 265 usable responses, 153 respondents (57.7\%) are male and 112 respondents are female (42.3\%). In terms of age distribution, 106 respondents (40\%) are 20 years old. 85 respondents (32.1\%) are 19 years old, 47 respondents (17.7\%) are 21 years old, 15 respondents (5.7\%) are 18 years old and below, and 12 respondents (4.5\%) are 22 years old and above. The students major in different technical and vocational programs which include aquaculture, culinary, electrical, architectural technology, creative multimedia, food processing and quality control.

The students in this study are found to have a high level of entrepreneurial career aspiration (mean $=4.32$, S.D. $=0.39$ ), attitude toward entrepreneurship (mean $=4.33$, S.D. $=0.43$ ), subjective norm (mean $=4.10$, S.D. $=0.46$ ) and entrepreneurial self-efficacy (mean $=4.05$, S.D. $=0.45)$. However, their entrepreneurial exposure is at a moderate level (mean $=3.97$, S.D. $=0.59$ ). 
Based on the Pearson correlation analysis, it is reported that there is a strong significant positive relationship between attitude toward entrepreneurship and entrepreneurial career aspirations $(r=0.597, p<0.01)$. Subjective norms $(r=0.327$, $p<0.01)$ and entrepreneurial self-efficacy $(r=0.362, p<0.01)$ were found to have a moderate relationship with entrepreneurial career aspirations. Entrepreneurial exposure was reported to have a low correlation with entrepreneurial career aspirations ( $r=$ $0.263, p<0.01$ ). Table 2 illustrates the correlation between the selected factors and entrepreneurial career aspirations.

TABLE 2: The relationship between the selected factors and entrepreneurial career aspiration.

Selected Factors
Attitude
Subjective Norm
Entrepreneurial Self-Efficacy
Entrepreneurial Exposure

\begin{tabular}{|c|c|}
\hline Pearson (r) & Sig. \\
\hline 0.597 & 0.01 \\
\hline 0.327 & 0.01 \\
\hline 0.362 & 0.01 \\
\hline 0.263 & 0.01 \\
\hline
\end{tabular}

\begin{tabular}{|c|}
\hline Strength \\
\hline Strong \\
\hline Moderate \\
\hline Moderate \\
Low \\
\hline
\end{tabular}

\section{Discussion}

This study found there is a strong correlation between attitude toward entrepreneurship and entrepreneurial career aspiration among the community college students. This result shows that if students have a positive perception toward the values, benefits and outcomes of entrepreneurship, they are likely to pursue entrepreneurial career. The strong association between attitude and entrepreneurial career aspiration is compatible with the proposition by [18] which stated that students make decisions to pursue an entrepreneurial career if they have the perception that entrepreneurial career entails greater utility compared to the other employment option. The strong correlation between attitude and entrepreneurial career aspiration in this study is consistent with past research which comprised of tertiary level students [2, 19-22]. The community college students, like other tertiary level students, are believed to have the ability to evaluate the possible outcomes and benefits of entrepreneurial career. Besides that, the respondents in this study have studied entrepreneurship components, which is likely to contribute to their high awareness concerning the possible outcomes of entrepreneurial career. As the findings in this study show that attitude has the strongest influence, thus entrepreneurship educators should focus more on raising the students' awareness regarding the benefits and values of entrepreneurial career.

This study also found that subjective norm has significant positive relationship with entrepreneurial career aspiration. This indicates that the perceived supports by the 
significant others and the surrounding culture are likely to influence one's decision to pursue entrepreneurial career. The finding concurs with past studies which found that subjective norm and entrepreneurial intention has significant positive relationship [2023]. The result of this study, however, contradicts the finding by [2] which found that there is no significant relationship between social norms and entrepreneurial intention. The difference is likely attributed to the number of items used in the instrument. In the research by [2], a single item measurement was applied, which is believed to have increased the measurement error.

For entrepreneurial self-efficacy, it is also reported that there is a significant positive correlation with entrepreneurial career aspiration. This is consistent with past research which indicated that students with high level of entrepreneurial self-efficacy have higher tendency to pursue entrepreneurial career [20, 22-24]. In this study, entrepreneurial self-efficacy is defined as the respondents' belief in their ability to execute entrepreneurial tasks, which include production, management, marketing and financial tasks. Students in this study were found to have a high level of entrepreneurial self- efficacy. The high level of entrepreneurial self-efficacy could be attributed to the entrepreneurship education exposed to the students. In community college, the students are not merely exposed to theoretical knowledge, but they are also required to perform hands-on activities which include drafting business plan and running business in campus. The confidence in performing entrepreneurial tasks is important as entrepreneurship is a complex process which requires application of energy and passion to deal with risks and uncertainties [25].

Furthermore, this study also found there exists a significant positive relationship between entrepreneurial exposure and entrepreneurial career aspiration. However, the relationship between the two variables is relatively lower. The result of this study is compatible with the findings by [26] which also found there is a significant positive relationship between entrepreneurial exposure and entrepreneurial intention. On the other hand, the finding of this study is in total contrast with the studies by [27] and [28] which found that entrepreneurial exposure has a significant negative influence on entrepreneurial intention. The difference in the findings could possibly be due to the quality of exposure. $[27,28]$ posited that quantity exposure could be offset by the negative experience. In this study, most of the students indicated they have a rather positive entrepreneurial exposure, either from work experience, family exposure or role model exposure. Thus, this is believed to have contributed toward the positive relationship between the two variables. 


\section{Conclusion}

This study found that there is a significant positive relationship between the selected factors with entrepreneurial career aspirations. Attitude toward entrepreneurship was reported to have the strongest association with entrepreneurial career aspirations. In short, the findings of this study provide greater understanding in predicting students' entrepreneurial behavior. Besides that, it gives insights for the government and respective agencies to develop effective policies and programs to promote and cultivate an entrepreneurial mindset among the students of technical and vocational education.

\section{Acknowledgement}

The authors would like to thank the administrators and students of community colleges for their cooperation and participation in this research.

\section{References}

[1] Ministry of Education. (2018). Graduates Tracer Study Report. Ministry of Education. Retrieved from: https://www.graduan.mohe.gov.my

[2] Krueger, N. F., Reilly, M. D., \& Carsrud, A. L. (2000). Competing models of entrepreneurial intentions. Journal of Business Venturing, 15(5), 411-432.

[3] Segal, G., Schoenfeld, J., \& Borgia, D. (2007). Which classroom-related activities enhance students' entrepreneurial interests and goals?: A social cognitive career theory perspective. Academy of Entrepreneurship Journal, 13(2), 79.

[4] Hisrich, R., Peters, M. \& Shepherd, D. (2008). Entrepreneurship (7th edition). McGrawHill. NY.

[5] Cumming, D., Johan, S., \& Zhang, M. (2014). The economic impact of entrepreneurship: Comparing international datasets. Corporate Governance: An International Review, 22(2), 162-178.

[6] Global Entrepreneurship Monitor, (2017). Global Entrepreneurship Monitor Global Report. Retrieved from: gemconsortium.org/report

[7] Norasmah, H. O., \& Salmah, I. (2011). Kecenderungan terhadap pemilihan kerjaya keusahawanan mengikut persepsi skim usahawan siswa. Jurnal Teknologi, 56, 4763.

[8] Amran, A., Ima, I. I., \& Siti, A. A. (2014). Determinants of entrepreneurial career: Experience of polytechnic students. Journal of Entrepreneurship, Business and 
Economics, 2(1), 21-40.

[9] Ajzen, I. (1991). The theory of planned behavior. Organizational Behavior and Human Decision Processes, 50(2), 179-211.

[10] Lent, R. W., Brown, S. D., \& Hackett, G. (1994). Toward a unifying social cognitive theory of career and academic interest, choice, and performance. Journal of Vocational Behavior, 45(1), 79-122.

[11] Shook, C.L. Priew, R.I. McGee, J.E. (2003). Venture creation and the enterprising individuals: a review and synthesis. Journal of Management, 23(3), 379-399.

[12] Department of Community College Education. (2017). Self-employed Graduates Data (2014 - 2016). Department of Community College Education, Ministry of Higher Education.

[13] Fraenkel, J.R., Wallen, N.E., \& Hyun, H.H. (2016). How to Design and Evaluate Research in Education (9th edition). McGraw-Hill Education.

[14] Wiersma, W. (2005). Research Methods in Education: An Introduction (6th edition). Massachusetts: Allyn and Bacon.

[15] Cochran, W.G. (1977). Sampling Techniques (3rd edition). New York: John Wiley \& Sons.

[16] Ary, D., Jacobs, L., Sorensen, C. \& Walker, D. (2014). Introduction to Research in Education (9th edition). Cengage Learning.

[17] Cohen, J. W. (1988). Statistical Power Analysis for the Behavioural Sciences (2nd edition). Hillsdade, NJ: Lawrence Erlbaum Associates.

[18] Douglas, E. J., \& Shepherd, D. A. (2002). Self-employment as a career choice: Attitudes, entrepreneurial intentions, and utility maximization. Entrepreneurship theory and practice, 26(3), 81-90.

[19] Norfadhilah, N., \& Halimah, H., (2010). Aspirasi kerjaya keusahawanan dalam kalangan pelajar institusi pengajian tinggi awam. Malaysian Journal of Education, 35(1).

[20] Wan Nur Azlina Ibrahim. (2014). Hubungan antara Sikap terhadap Keusahawanan, Norma Sosial, Efikasi Keusahawanan, Kompetensi Keusahawanan dan Tekad Keusahawanan dalam kalangan Pelajar IKBN dan Kolej Komuniti. Unpublished master's thesis. Universiti Putra Malaysia.

[21] Lee-Ross, D. (2017). An examination of the entrepreneurial intent of MBA students in Australia using the entrepreneurial intention questionnaire. Journal of Management Development, 36(9), 1180-1190. 
[22] Marire, E., \& Dhurup, M. (2018). Antecedents of entrepreneurial intent: A crosscountry comparison of generation y university students. Journal of Reviews on Global Economics, 7, 195-206.

[23] Asghar, M. Z., Seitamaa-Hakkarainen, P., \& Nada, N. (2016). An analysis of the relationship between the components of entrepreneurship education and the antecedents of theory of planned behavior. Pakistan Journal of Commerce and Social Sciences, 10(1), 45-68.

[24] Austin, M. J., \& Nauta, M. M. (2016). Entrepreneurial role-model exposure, selfefficacy, and women's entrepreneurial intentions. Journal of Career Development, 43(3), 260-272.

[25] Kuratko, D.F. (2009). Introduction to Entrepreneurship (8th edition). South- Western Cengage Learning.

[26] Ali, A. I. (2014). Factors Influencing Self-employment Intention among Nigerian Post-graduate Students of Universiti Utara Malaysia (UUM). Doctoral dissertation, Universiti Utara Malaysia. Retrieved from etd.uum.edu.my.

[27] Krueger, N. (1993). The impact of prior entrepreneurial exposure on perceptions of new venture feasibility and desirability. Entrepreneurship: Theory and Practice, 18(1), 5-22.

[28] Zhang, Y., Duysters, G., \& Cloodt, M. (2014). The role of entrepreneurship education as a predictor of university students' entrepreneurial intention. International Entrepreneurship and Management Journal, 10(3), 623- 641.

\section{Appendix: Questionnaire Items}

\section{Items}

\section{Section A: Entrepreneurial Career Aspiration}

I will choose an entrepreneurial career once I have completed my study.

I never aspire to own a business.

I prefer to be an entrepreneur rather than work for others.

I keep myself updated with the news of successful entrepreneurs.

I will be an entrepreneur within 5-years after my study.

I have an aspiration to be a successful entrepreneur.

I am sure that I will run my own business in the future.

I wish to be a boss. 


\section{Section B: Attitude toward Entrepreneurship}

I can gain high income by becoming an entrepreneur.

I will be able to enjoy a comfortable life by becoming an entrepreneur.

Entrepreneurial career enables me to contribute to the nation's economic development. I can give meaningful contribution to the society if I pursue an entrepreneurial career. I can develop my potential easily by becoming an entrepreneur.

An entrepreneurial career provides me opportunities for career development at the international level.

To me, the entrepreneurial career is not a popular one.

An entrepreneurial career gives me high level of work satisfaction.

The entrepreneurial career provides me with intellectual challenges.

An entrepreneurial career provides me opportunities for further studies.

I will be able to use new technology if I choose an entrepreneurial career.

An entrepreneurial career gives me high social status.

\section{Section C: Subjective Norm}

My father/guardian encourages me to choose an entrepreneurial career.

My mother/guardian encourages me to choose an entrepreneurial career.

Lecturers in the Community College discourage me from choosing an entrepreneurial career.

My friends encourage me to choose an entrepreneurial career.

My teachers support me in choosing an entrepreneurial career.

My siblings support me in choosing an entrepreneurial career.

The culture in Malaysia supports entrepreneurial activities.

Generally, society members in this nation can accept an entrepreneurial career.

\section{Section D: Entrepreneurial Self-Efficacy}

I believe I am able to:

- prepare estimated/projected income statement.

- determine product/service to fulfil customers' needs.

- obtain appropriate tools for producing my products/services.

- delegate tasks to employee efficiently.

- determine financing needed to start a business. 
- determine suppliers who are able to supply sources for my production activities.

- coach employees.

- select target markets.

- complete Ioan application process.

- handle employee complaints.

- take corrective measures if there is any defect in my products.

- determine strategic business location.

- implement procedures for managing debt.

- select pricing strategies.

- produce products in accordance to the stipulated time frame.

\section{Section E: Entrepreneurial Exposure}

My parents/guardian have their own business.

My family's knowledge of starting their own business has been positive.

I have worked in my family business.

I have no working experience.

My experience of working has been positive.

I have a role model, operating his/her own business. (The role model could be a friend, relative or neighbor).

The role model's action positively affects my views on starting a business. 